\title{
Charismatic Masculinity in David Malouf's Fiction
}

Don Randall

67 Towards Midnight', the story at the centre of David Malouf's collection Every Move You Make (2006), presents a singularly attractive masculine figure, a midnight swimmer who sneaks dips in a private pool. He rapidly becomes, for the pool's female owner, an alluring and mysterious guest rather than an alarming intruder. The swimmer says nothing in the course of the story, but he does much. Intensely physical, his 'powerful strokes', by which he 'hurl[s]' himself through the water, assert the primacy of embodied life $(138,149)$. Yet he also transcends the body's real limits: his swimming is 'Effortless', 'Weightless', and his 'energy' and 'breath' seem to 'have no end' (149). He is unmistakably godlike - a version of the angel that inhabits Malouf's poetry and fiction in many forms (see Randall 14-15). As he swims, 'streamers of light' trail from his shoulders; when he springs out of the pool, with sudden grace, 'his head [is] streaming moonlight' (138). The pool's filter boxes announce his visitations by 'dancing and beating the air. ... Like the arrival of wings' (149). This venturesome being enlivens the world in which he intervenes: the pool, when he enters it, 'expand[s] and contract[s] like a living thing'; the pool's owner, a woman dying of cancer, witnesses his trespass and is thus moved to 'awareness of her own body ... as a thing alive and part again of the living scene' (138). This masculine figure discovers his importance in being seen; he is a spectacular presence whose performance of self has a redemptive impact upon his spectator.

Male characters thus touched by grace - what one may call, more denotatively, charismatic male characters - have made frequent appearances in Malouf's fiction, typically in crux moments or moments of resolution. An Imaginary Life (1978), the author's first international success, presents the Child, a wild boy reclaimed for human society by the exiled poet Ovid. In the novel's final passages, the Child is clearly marked by the divine or angelic: as the dying Ovid watches, the Child wades naked in a luminous stream, with sunlight on his shoulders and waterreflected radiance around his feet. Then finally, 'He is walking on the water's light ... above the earth, above the water, on air' (Imaginary 152). The initial readers of An Imaginary Life may not have been inclined to measure the significance of the Child's maleness, to wonder if this maleness is not a key component of his special grace. However, Malouf's more fully developed career certainly provides 
the grounds for such gender-focused questionings. Child's Play of 1982 presents the charismatic figure known as 'the author', in response to whom the whole of the narrative is ordered. Fly Away Peter, also published in 1982, stages in its final passages the inspiring spectacle of a seemingly divine male figure, a surfer gliding over sunlit water - and this spectacle is feelingly witnessed by the novel's most important female character. The most recent novel, The Conversations at Curlow Creek (1996), organises much of its narrative around Fergus, an unmistakably charismatic male character who amply demonstrates the special power of intervening in and transforming other worlds and other lives. Malouf's two most recent major publications - as of the time of this writing, 2009 - have been shortstory collections. As the brief opening discussion of the story 'Towards Midnight' begins to demonstrate, the second of these collections, Every Move You Make, contributes significantly to Malouf's portrayals of charismatic masculinity, and of men's and women's variously articulated relationships with it.

The examination of charismatic masculinity can further critical understanding of Malouf's representation of gender in his fiction, but this critical undertaking must begin by asserting that gender, and masculinity in particular, are more crucial in the field of the author's concerns than has been acknowledged by criticism to date. Ivor Indyk's David Malouf convincingly argues that male same-sex desire is an organising concern in the writings of Malouf's early and middle career. Although a very adept reader, Indyk does not work much toward a broader view of the place and importance of masculinity in Malouf. He offers some commentary on fathers and paternal legacies, and occasionally ventures generalising reflections upon masculine character. Gillian Whitlock, in a critical evaluation of Malouf's autobiographical 12 Edmondstone Street, astutely observes that this text manifests 'that drive to autonomy and mastery which defines masculine individuation' (82); however, this recognition only begins to account for the full range of Malouf's representation of masculine character and perspective. Leigh Dale and Helen Gilbert, in a study that focuses most closely on the play Blood Relations, consider 'the repressed and displaced desires and fears which inflect the friendships and rivalries between men' (93), but this point of concern is subordinated to their examination of 'exchange between place and body' in Malouf's texts (86). Since the mid-1990s, place and body, along with language and textuality, identity, nation, ethnicity (especially in relation to Aboriginality), history and myth-making have established themselves as key topics for Malouf criticism. Important articles treating one or more of these topics have appeared, but masculinity does not find a significant place in the debates. ${ }^{1}$ Don Randall's David Malouf notes at the outset Malouf's 'preoccupation with masculine experience' (4), but then engages critically with this preoccupation only in brief sallies through the rest of the monograph. Recently published, career-reviewing interviews by Colm Tóibín and Lee Spinks cover familiar topics in engaging ways, both eliciting quite ample autobiographical details from their subject. Tóibín's interview addresses such topics as place, history (and the twentieth century's wars),

1 A short list of field-defining contributions to Malouf criticism since the early 1990 s would need to include Spinks, Ashcroft, Taylor ('The Bread'; 'Origin') and Brittan. 
childhood and youth, but without bringing the question of gender identity, and specifically masculinity, under scrutiny. Spinks queries the author about Australian identity, place, the wars, history, mythology, and otherness. Notwithstanding its absence from these lists, masculinity is demonstrably a principal Malouf topic, one that is often a matter of negotiation in the author's text-making, alongside and in conjunction with other more thoroughly documented concerns.

Enabling developments in contemporary gender studies can and should be brought to bear on Malouf's fiction. Of particular importance is R.W. Connell's sense of plurality and hierarchy, of various masculinities assembled under a dominant paradigm and enjoying varying degrees of social validation. Masculinity reconceived in the plural then needs to be considered in the light of Judith Butler's groundbreaking theorising of gender identity as a 'stylized repetition of acts' in which 'gender attributes ... are not expressive but performative' (179, 180 ), not revelatory, but productive and constitutive. Although Malouf's versions of masculinity are various, one type, charismatic masculinity, is clearly the prioritised or ideal form. It is represented as a social rather than a personal value, not as a structuring code for the subjective organisation of individual males, but a high-impact sign system that reshapes and inflects the lives and subjectivities of all those, male and female, who witness and interpret it. In Malouf, it is the dominant form of masculinity in relation to which other forms take shape.

The title story of Every Move You Make focuses attention on a mysterious and charismatic male character, whose presentation of masculinity has several points of similarity with that of the swimmer in 'Towards Midnight'. Here again, the most important witness, or spectator, is female. And again, the spectacular male character has no message or vision to impart; he has only the spectacle of himself to offer, and he offers this spectacle without self-interest or even self-awareness. Mitchell Maze's distinction resides in the impact he has on those into whose lives and worlds he wanders. In boyhood, he has had a brief but dazzling success as a child movie-star, as the (unsurprisingly masculine) idealised embodiment of the Australian national character. In his maturity, he is a house builder, part architectural designer and part contractor; his business, his vocation, is quite literally the transformation of other people's lives by the transformation of their living spaces. His immediate social impact is also noteworthy. Like the universally admired Fergus of Conversations, Mitch is ascribed 'extraordinary charm', and 'intense presence, of which he himself seem[s] dismissive or unaware'. In the course of a social gathering, he wanders freely 'from group to group', repeatedly 'unsettle[s] the room' and 'refocuse[s] its energies' (67). In this again, he recalls Fergus, the charismatic wanderer-adventurer. But Mitchell Maze is also a man who appears to have a hidden second self, an inner 'darkness' (76), a 'secret' that creates a 'distance' from others - and this distance is a large part of his allure (80). Indeed, all surface aspects of Mitchell Maze - among others, his rough-hewn physicality, his easy-going, broadly dispersed sociability, his refusal of self-promotion, his indifference to admiration, his spareness of speech - serve to create and maintain his very appreciable portion of masculine mystique. 
In the later stages of the story, one comes finally to understand something of Mitchell Maze's psychology: he has a hulking, mentally handicapped brother whom almost no one knows about. This unfortunate secret sharer of his life makes Mitchell feel irremediably at odds with his own charm, with the overpowering and indestructible 'beauty' his partner Jo (the story's only other major character) finds in him. The secret brother, Jo realises, entirely transforms the interpretation of her partner's personal history and inner life. Mitch's indifference to - and his invariable refusal of - care and approval, his life's unrelentingly 'reckless exposure to a world of accident' (85), must now be understood as self-castigation. He clearly has had to endure a deep, seemingly insoluble problem with selfimage and social connectedness. He is not self-contained, not self-possessed; he does not have the assured self-sufficiency that is presumed to be the generative core and sustenance of the charismatic male's social presence. Mitchell Maze's masculine mystique really is the production of his beholders, of all those who have created him as a masculine spectacle in accord with the needs and desires of their own subjectivities. His story's resolution reveals, however, that Mitch shares with the houses he builds the character of being unfinished, unresolved. He portrays quite precisely the modern subject as discerned by Freud and Lacan, the subject constituted by and upon lack, the subject that must assume its castration, its insufficiency. Mitch's social impact, his social power, cannot be referred to some inner truth of character. His charismatic masculinity does not serve to resolve his inner life or sense of self; it manifests itself only in its effects upon others, upon all those who find in themselves a need for Mitch's particular performance of gender identity.

The story 'Elsewhere' presents an elsewhere of masculine experience, very different from, but clearly related to, that of Mitchell Maze. In the course of a trip to Sydney for his sister-in-law's funeral, a working-class man from a small inland town learns a curiously humbling lesson about how slight his impact on the world is, how little he possesses of the world-transforming power that is so essential to other male characters, in other Malouf stories. Andy Mayo seeks to find and claim, even if only briefly, a personal value in his experience and enactment of masculinity. He begins his one-day journey 'full of expectation', rediscovering his youthful sense of his life as 'golden and inextinguishable' (156). His wish is 'to range out'; he feels he is confronting 'a set of possibilities that might not come his way again' $(161) .{ }^{2}$ And at his sister-in-law's wake he does manage to find an approximate version of an adventure: after brief party conversation, a woman pushes her tongue into his mouth and gropes him quite provokingly. But Andy is not very easy in the recognition of "how little of the initiative was his' (163), and he is reduced to quite abject and sweaty confusion when the woman suddenly 'disengage[s]' and 'set[s] him down' (164). He is still more thoroughly disorientated when he examines a book of poetry dedicated to his sister-in-law and strikes upon the word 'cunt' - in print, in a poem. Shortly

2 Andy Mayo thus affiliates himself with what Indyk describes as 'an essentially masculine desire to reach out to encompass the world as a whole' (103). 
afterward, he leaves the wake, ushered on his way by the 'Goodbye' of a few 'strangers' as 'incurious' about his departure as they had been about his arrival (165). Andy is then overcome by an acute sense of his own 'isolation' and that of those around him (167) - a sense that a life is lived at an unbridgeable distance even from those with whom one is close, a sense that one's understanding of self and of the world is not deeply shared. Ultimately, however, Andy achieves a curious sense of freedom that his experience has given him. His incapacity to enter and understand elsewheres, other worlds, the worlds of others, allows him to specify his own vision and understanding - limited though it may be. In relation to personal life and the sense of self, failure to discover oneself as a charismatic male is not an important failure. Andy's story provides, however, an additional, unusual perspective upon charismatic masculinity. His case shows (as the Mitchell Maze story does in a different way) that it is difficult, perhaps impossible, for men to put the power of charismatic masculinity to personal, lifeordering, self-organising use.

The story 'War Baby' presents another instance of a male character who feels the appeal of the charismatic masculine ideal but has trouble finding for himself a satisfactory relationship with it. Once selected for induction to service in Viet Nam, young Charlie Dowd commits himself, mind and body, to the prospect of this service, believing it will bring a needful order and direction to his life. Crucially, he has a sense that he is undertaking a performance, a particular masculine staging of self. In anticipation of his mobilisation, he takes to wearing his dead father's old 'air force greatcoat' and gets an excessively short hair cut. He 'contemplate[s] himself in the mirror' and finds with satisfaction that 'he really look[s] the part' (91). He keeps a personal notebook, but works with it only at the pub, in public, which suggests that the notebook's real value is as a prop that allows him to be seen reading and writing his 'Bemused speculations' (92). He expends much time and attention trying to discover what impression he makes, and has made, on others. He spends still more time 'making a show of himself, and enjoying it too' (96). He believes that if you have 'Guts', some intuition and some luck, 'You could present yourself as you wanted to be seen and then try to live up to it' (97). As he proceeds with the self-staging that aims at producing his real self and real life, he begins 'to see, in the events he ... organize[s] for himself, the outline of what he was to be' (112). And even though this vision remains incomplete, a disappointed dream, a somewhat matured Charlie, on the far side of his war experiences, is 'Intrigued still by the spectacle of his own existence' and 'Still making himself up out of what others saw in him' (128).

Charlie Dowd understands that a man who embodies the masculine ideal will inhabit the world as a focal presence. Crucially, however, Charlie hopes to get back from others the meaning and value of the spectacle of self. In his quest for a validated masculinity, he differs radically from Mitchell Maze and the swimmer of 'Towards Midnight', neither of whom is self-focused, self-conscious, or contrived in their self-presentation. Charlie Dowd's story nonetheless ends on a quietly optimistic note, as Charlie glimpses the more essential, deeper element 
of the masculine ideal: the power to transform the worlds and the lives of others. A period of protracted rain in the region of Charlie's inland town briefly creates expanses of water inhabited by seagulls. A small child entranced by this new world happens to mistake Charlie for 'the presiding genius' of wondrous transformation, 'and for a moment Charlie actually [feels] a breath of what the child's belief ha[s] accorded him' (132). Thus, Charlie briefly experiences, or at least glimpses, charismatic masculinity. In constant quest to transform himself by the impact he has on others, this character sidesteps, at least for one magic moment, all questions of authenticity in masculine experience, all assumptions of an inward residing, inwardly discovered masculinity. The spectacle of self is man-making for Charlie, not man-manifesting.

'The Valley of Lagoons', the first and longest story in Every Move You Make, is intensely concerned with relationships between men, and also with the ways in which specific places may inflect men's sense of themselves and their relations with other men. Thus the story works upon a close transaction between masculinity and place, a thoroughly acknowledged key topic in Malouf, even as 'Towards Midnight' coordinates masculinity with Malouf's well-documented interest in the body and bodily life. At the centre of the story is the inception and short-lived development of a fairly standard heterosexual romance: smalltown boy meets small-town girl, who is unsurprisingly the sister of a friend. The story's resolution is precipitated by a wounding of the disappointed young male, which is, at the primary level of interpretation, his wounding by love. And yet the main bulk of the story's sixty pages is devoted to the delineation of masculine community, which has heterosexual love as only one of its components, and not in any obvious way a key component. Indeed, Stuart's love for Katie is in large part an extension of his curiosity about her younger brother Angus, whom Stuart seeks insistently to understand, and whose favourable attention he tries repeatedly to gain. Angus (also the story's first-person narrator) reflects that Stuart desires recognition for 'the effort he was making to enter my world' and that this effort is also an attempt to make the narrator see him differently (17). This spatial rendering of Stuart's relational effort - he wants to enter Angus's world - manifests the story's deep concern with the relationship between men and place, and with spatially ordered conceptions of masculinity.

Although the story's most meaningful place, the Valley of Lagoons, has in its naming a suggestive feminine allure, it is thoroughly appropriated for masculine use - a place of exclusively male gatherings, a place of masculine rites of initiation and passage. It is presented as a place where the deep truths of masculine identity and masculine community can be discovered and explored, thus recalling the estate turned sanctuary that enables Jim Saddler and Ashley Crowther of Fly Away Peter to recreate themselves and their relationship. As Angus solemnly observes, 'Fellows who went out there were changed' (4). Here apparently is an alternative paradigm for masculinity in Malouf's collection: rather than concentrating on men's power to transform, this story posits a power of place that can transform - even create - men. Further examination reveals, 
however, that this masculinity is really only mediated by place and has its true source elsewhere, in the world-making masculinity that was required and shaped by old settler-colony realities.

Angus, when he finally gets his chance to make the trip to the Valley, reflects upon grandfathers: these men 'had given their names to streets, towns, shires all over the North; these 'sternly soulful and patriarchal' men had lived and worked 'in defiance of conditions so hard that to survive at all a man had to be equally hard in turn' (39). They made their world 'with their bare hands', and did 'whatever had to be done to make it theirs in spirit as well as fact. Brooking no question, and suffering ... no regrets, since such work was an arm of progress and of God's good muscular plan for the world' (39-40). This anthem to the great colonial patriarchs - who evidently were place-making much more than placemade - has one or two touches of discreet irony, such as the mention of 'God's good muscular plan', alluding to 'muscular Christianity', a prominent nineteenthcentury model for masculinity. ${ }^{3}$ But this ironic touch notwithstanding, Malouf's perspective must remain a matter of speculation, because ironic distance, if there is any, belongs to Angus, the young narrator, and Angus, one should note, eagerly undertakes his initiation to the version of masculinity that founds itself on the mythic work of the great patriarchs of by-gone days.

The outcome of Angus's initiation is ambiguous: on one hand, Angus moves within the Valley believing 'It was myself I was moving into'. This conforms perfectly with the understanding of the trip to the Valley as an initiation into a fuller, more self-possessed masculinity. Yet Angus also affirms that he is not transformed, that he takes fuller possession of his 'old self, not a new one' (50). Then comes the wound, the accidental lover's wound that Stuart submits to, uncomplainingly, for the love of Angus's sister; the wound for which Stuart is glad to have a preferred masculine witness, Angus. At this point Angus's understanding of himself and other men is transformed, but by the spectacle, provided by another young man, of masculine vulnerability. The transformative power of masculine spectacle is again confirmed, but as in 'Every Move You Make' the spectacle's ultimate revelation is a glimpsed view of a man's troubled, unstable, ill-defined inner life, of 'the heart and its confusions, the mess of need, desire, hurt pride, and all the sliding versions of himself' (55). This version of masculinity contrasts sharply with the triumphant toughness of the colonial forefathers, but it is produced, one must note, wholly within male community - with mediation perhaps, but without other and external agencies. For all that it may give evidence of disorder in the arrangement of its component parts, masculinity maintains an insular and autonomous character. And yet the story baffles - or at least ironises - this interpretation in its concluding passage, in which a thrown-together medley of men in a pick-up truck - some young, some old, some in the cab, some in the back - speed along through darkening twilight and sing out a song in spontaneous chorus. The song is 'A doleful tune, almost a

3 Muscular Christianity was propounded most famously by one of the inaugurating authors of boys' fiction, Thomas Hughes, in his immensely successful Tom Brown's Schooldays. 
dirge, full of old hurt'; the song is 'the sad but consoling anthem of some loose republic of the heart'; the song is 'Goodnight, Irene' (59). The feminine element thus slips back into the heart - the troubled, hotchpotch heart - of masculine experience and self-expression, and asserts itself as the stuff and substance of masculinity's choric song.

The story's resolution makes its interpretation particularly difficult, multiplying possible readings. The singing men are acknowledging their identification with Stuart, with Stuart's doleful spectacle, but what is it that spurs and maintains this identification? One may suggest first that men - particularly small-town Queensland men of Anglo-Celtic background - tend to evade or disavow their inescapable investment in femininity, their self-defining relationship with the feminine, and that they do so even as they continue to enact this investment, this relationship. But the curious final paragraphs may also be taken to demonstrate that investment in femininity and relationship with the feminine constitute a time-honoured, well-cultivated alibi for forms of identity and community shaped by homosocial practices, homosocial identifications, and homosocial bonds. One may then subscribe to a both/and, even a both/and in an alternating rhythm, whereby men go back and forth between disavowal and the alibi. No matter which interpretation one favours in this array of possibilities, it never becomes clear what degree of agency femininity really has in the making of men. It is however clear that men do not tend to recognise and acknowledge fully the agency of the feminine in man-making.

This question of feminine agency directs attention to the last two stories in Malouf's collection, 'Mrs Porter and the Rock' and 'The Domestic Cantata'. The first of these associates itself with 'Every Move You Make' and 'Towards Midnight' in that a woman character provides the focalising consciousness. The representation of feminine subjectivity is a notably important concern, but as with the other two stories, the focalising woman is very concerned with men, and more specifically with the impact men have on feminine experience. Mrs Porter's existential conundrum has very much to do with the fact that 'She had never fathomed what men were really up to, what they wanted' (195). 'The Domestic Cantata' is, however, appreciably more revealing of the importance Malouf accords to feminine agency in the fashioning of male subjectivity.

At the centre of 'The Domestic Cantata' is a couple, Sam and Maggie - middleclass, comfortable, married with children. He is a composer, she a singer. To put the case more precisely, she gives her voice to his compositions, a relational structure that recalls the old, familiar, but these days rather unpalatable story of the male artist and his model/muse/mistress, and also suggests, more troublingly, that femininity is a spectacle for male pleasure and under masculine control. The relationship appears, on superficial examination, to affirm a recognisable representational 'myth of woman': 'she is simply revealed by the genius of the artist' (Pollock 122). Evaluating the story requires, however, a careful consideration of the adjustments Malouf makes to the conventional, gendered narrative of dominance and subordination. 
Before examining the subtleties of the central marital relationship, however, one should note that Sam does in some ways figure forth a sort of benign patriarch. Concerning his relationship with his children, one learns, 'Their father's alteration of moods constituted the weather of their lives, which ... it was useless to quarrel with or resist' (216). Sam is also 'proprietorial' in quite conventional ways; he is proprietorial about various things, but especially about the women in his life (228). The interpretation of the character is made more difficult and complex, however, by the fact that one can find in Sam something of Malouf's masculine ideal; he has the charismatic capacity to intervene in others' lives, most particularly in women's lives, and to transform their sense of themselves and their worlds. This relational paradigm hearkens back to Remembering Babylon: Jock McIvor, inspired by Gemmy to re-envision his world, passes the enlivening inspiration on to his wife by means of a tiny white flower: 'It was the way he held it, ... and the attention he gave it, that touched her and made its whiteness come alive. When she looked round the whole slope was shining with it' (110). A similar relational dynamic shows itself in The Great World, when the all-remembering Digger Keen reproduces exactly, for the benefit of his beloved Iris, the life-affirming gift that is Hugh Warrender's poetry.

Sam is a successful composer whose music affects the people who listen to it, but his social agency discovers itself in more specific and interesting ways. Sam has put to music certain works of an American poet named Diane Novak. His compositions, however, have not sought out music to fit Diane's poems; they have 'Released ... the music that was already in them and in her' (225). Sam ostensibly has entered into the world of the poetry; he has intervened and transformed it; he has enabled the poetry and its author to discover new being, new life. Sam thus aligns himself, albeit somewhat obliquely, with Diane's young lover Scott, a more obviously charismatic male, who is 'amazing', who has 'a fund of attention' and 'youthful excitement' that 'he bestow[s], in an unselfconscious way, on everything in his vicinity' (228).

Sam's creative relationship with his wife Maggie is similar to that which he discovers with Diane Novak. Toward the end of the story, Maggie does an impromptu performance of Sam's new, not yet complete composition, his new cantata:

sounds he had with so much difficulty drawn out of himself, now poured forth, without effort it seemed, on her breath, and on the same breath climbed and spread. So much part of her, of her actual being, yet entirely independent. As they had been of him too, even before she took them over, took them into herself, gave them life. (240)

Thus, the music is something Sam draws out of himself, yet it is also independent. It is also independent of Maggie, although she takes it into herself and gives it embodied life. This sounds oddly like the Virgin Mary's transaction with the Holy Spirit, whereby, as medieval theologians speculated, the Holy Spirit entered Mary, chastely, through her ear. Yet one must stress that Sam is not the Holy Spirit, the music is. The gender politics of Sam and Maggie's creative collaboration 
is subsumed in the autonomous power of the magic stuff, the music itself, the art. However, Malouf's characterisation of Maggie's performance of Sam's music develops further, and somewhat differently, when the singing Maggie is said to be 'miraculously translating into this other self he had discovered for her, and which her breath, pushed almost to its limit, was once again amply reaching for' (240). Maggie translates her life, her self, into a new self Sam has discovered and composed for her. Her breath does not inspire the new form of being the music offers; her breath reaches for new form, which stands at the very limit of what her voicing can grasp and hold. In this one can again perceive the paradigm of charismatic masculinity in Malouf. Through the medium of his musical compositions, Sam intervenes in and transforms Maggie's most intimate experience of herself and her life. However, Sam's self-expression and selffashioning have no site of enactment other than Maggie's 'giving voice to', her Sam-rendering vocal performance: 'the true voice of what he might have in him was Maggie's' (230). Sam only comes into his own being by the transformation he enables in Maggie.

Although Sam is most adept at providing self-fashioning performances to others, he also is personally enriched, and in this he differs sharply from Mitchell Maze. But the transformative impact Sam has on others conforms quite neatly with the paradigm of charismatic masculinity that Malouf's fictions frequently delineate. This form of masculinity is other-orientated, in large part catalytic. It manifests no essential character, represents no specifiable assembly of traits or elements. Far from being autonomous and self-defining, it enacts itself in social engagements, finding its form and value in its effects, in the reactions and transactions it provokes or enhances. Various versions of masculinity find their place in Every Move You Make and in other Malouf works, but these masculinities typically refer, if only implicitly, to the charismatic paradigm. It is unclear if Malouf really favours any of the forms and distributions of masculinity he puts forward. He may be aiming simply to record his social world as he sees and understands it. Certainly, his writing does not apply itself to subverting empowered, conventionalised understandings of gender identity - a principal aim of Judith Butler's gender studies. But Malouf, particularly in his recent fictions, does adjust and revise the understanding of masculinity and its particular social agency; he does rethink, and strives also to think beyond, the preconceptions and conventions that typically characterise the representation of masculinity, as is evidenced most clearly by his creative engagements with the troubled selffashionings of such characters as Mitchell Maze, Andy Mayo, or Charlie Dowd.

\section{WORKS CITED}

Ashcroft, Bill. 'Habitation.' New Literatures Review 34 (1997): 27-42.

Brittan, Alice. 'B-b-british Objects: Possession, Naming, and Translation in David Malouf's Remembering Babylon.' PMLA 117.5 (Oct. 2002): 1158-71.

Butler, Judith. Gender Trouble: Feminism and the Subversion of Identity. New York: Routledge, 1999. 
Connell, R.W. Masculinities. Sydney: Allen \& Unwin, 1995.

Dale, Leigh, and Helen Gilbert. 'Edges of the Self: Topographies of the Body in the Writing of David Malouf.' Nettelbeck, 85-100.

Indyk, Ivor. David Malouf. Melbourne: Oxford UP, 1993.

Lacan, Jacques. 'The Signification of the Phallus.' Ecrits: A Selection. Trans. Alan Sheridan. New York: Norton, 1977. 281-91.

Malouf, David. An Imaginary Life. 1978. New York: Vintage, 1996.

- The Conversations at Curlow Creek. 1996. Toronto: Vintage, 1998.

—. Every Move You Make. London: Chatto \& Windus, 2007.

- Fly Away Peter. 1981. New York: Vintage, 1998.

- Remembering Babylon. 1993. Toronto; New York: Vintage, 1994.

Nettelbeck, Amanda, ed. Provisional Maps: Critical Essays on David Malouf. Nedlands, WA: Centre for Studies in Australian Literature, 1994.

Pollock, Griselda. Vision and Difference: Femininity, Feminism, and Histories of Art. London: Routledge, 1988.

Randall, Don. David Malouf. Manchester; New York: Manchester UP, 2007.

Spinks, Lee. 'Allegory, Space, Colonialism: Remembering Babylon and the Production of Colonial History.' Australian Literary Studies 17.2 (Oct. 1995): 166-74.

—. 'An Imaginative Life: David Malouf Interviewed by Lee Spinks.' Journal of Commonwealth Literature 44.2 (2009): 5-14.

Taylor, Andrew. 'The Bread of Time to Come: Body and Landscape in David Malouf's Fiction.' World Literature Today 74.4 (2000): 715-23.

. 'Origin, Identity and the Body in David Malouf's Fiction.' Australian Literary Studies 19.1 (May 1999): 3-14.

Tóibín, Colm. 'Interview: David Malouf.' Bomb 101 (Fall 2007): 26-31.

Whitlock, Gillian. 'The Child in the (Queensland) House: David Malouf and Regional Writing.' Nettelbeck, 71-84. 
Copyright of Australian Literary Studies is the property of University of Queensland - School of English, Media Studies \& Art History and its content may not be copied or emailed to multiple sites or posted to a listserv without the copyright holder's express written permission. However, users may print, download, or email articles for individual use. 